\title{
PENINGKATAN KEMAMPUAN KOMUNIKASI MATEMATIS SISWA SD KELAS V MELALUI PEMBELAJARAN DENGAN STRATEGI REACT
}

\author{
Elfi Rahmadhani \\ Jurusan Tadris Matematika STAIN Gajah Putih Takengon Aceh Tengah, Aceh \\ Jl. Yos Sudarso/A. Dimot No. 10 Takengon Aceh Tengah, Aceh \\ elfi_qtez@ymail.com
}

\begin{abstract}
Abstrak
This article was written aimed to determine (1) mathematical communication skills of students who use the REACT strategy better than students using the conventional learning model, (2) mathematical communication skills of students who have prior knowledge of high, medium and low with using REACT strategy better than the students who used conventional learning models, and (3) the interaction between early learning approach with the ability of students to affect an improved mathematical communication skills of students. Samples were fifth grade elementary school students 03 and 04 Solok City academic years 2012/2013 as many as 56 people. Research data on study result of the students were collected through initial skills test, pretest and posttest. To see the improvement, the analysis used the gain. Based on the results of this study concluded that an increased mathematical communication skills of students using REACT strategy is better than using the conventional learning, and there is no interaction between early learning approach with the ability of students to affect an improved mathematical communication skills of students.
\end{abstract}

Keyword: mathematical communication skills, REACT strategy

\section{PENDAHULUAN}

Matematika merupakan pelajaran yang penting diajarkan disetiap jenjang pendidikan. Dengan matematika, siswa dilatih dan dibekali untuk dapat berfikir logis, sistematis, kritis dan dapat mengkomunikasikan ide secara baik dan benar Ada beberapa kemampuan matematis yang perlu dikembangkan oleh siswa, yaitu pemecahan masalah (problem solving), penalaran (reasoning), komunikasi (communication), penelusuran pola atau hubungan (connections), pemahaman konsep dan representasi (representtation) (Jihad, 2008). Namun, kemampuan komunikasi matematis siswa belum berkembang secara optimal.

Melalui observasi yang dilakukan pada tahun 2012, untuk mengetahui kemampuan matematis siswa SDN Kota Solok, didapat bahwa kemampuan siswa dalam memahami dan mengkomunikasikan suatu soal cerita masih lemah. Hal ini terlihat dari analisis terhadap lembar jawaban ujian Mid Semester 1 siswa. Sebagian siswa mengalami kesulitan pada saat menyelesaikan permasalahan dalam bentuk soal cerita. Mereka mencantumkan hasil akhir tanpa memberikan penjelasan jawaban yang telah mereka dapatkan, sehingga guru tidak dapat melihat ide atau gagasan yang digunakan oleh siswa dalam membantu mereka menyelesaikan permasalahan. Kesulitan siswa ini dikarenakan mereka kurang dilibatkan secara aktif dalam pembelajaran.

Kemampuan siswa dalam mengkomunikasikan ide, gagasan yang mereka miliki ketika mereka diberikan suatu permasalahan, masih lemah dan belum terealisasi dengan baik. Jika mereka paham dengan materi yang diberikan, maka mereka dapat mengkomunikasikan baik secara lisan maupun tulisan tentang apa yang mereka ketahui. Kemampuan siswa dalam berkomunikasi secara matematis ini penting diketahui oleh guru, untuk melihat dan mengevaluasi sejauh mana seorang siswa telah memahami materi yang dipelajari. 
Kemampuan komunikasi matematis siswa diidentifikasi melalui indikator (1) menghubungkan benda nyata, gambar dan diagram ke dalam ide matematika; (2) menjelaskan ide, situasi dan relasi matematika secara lisan atau tulisan dengan benda nyata, gambar, grafik dan aljabar; (3) menyatakan peristiwa sehari-hari dalam bahasa atau simbol matematika; (4) mendengarkan, berdiskusi dan menulis tentang matematika; (5) membaca presentasi matematika tertulis dan menyusun pernyataan yang relevan; (6) membuat konjektur, menyusun argumen, merumuskan definisi dan generalisasi; (7) menjelaskan dan membuat pertanyaan tentang matematika yang telah dipelajari (Sumarmo dalam Iskandar: 2010).

Kemampuan komunikasi matematis siswa dapat dikembangkan dengan memperhatikan materi pelajaran dan strategi yang digunakan oleh guru. Kesesuaian uraian materi yang disajikan dengan SK dan $\mathrm{KD}$, sistematika penyajian dan peluang yang diberikan kepada siswa untuk melakukan observasi, investigasi dan menemukan sendiri konsep materi pelajaran, mendukung peningkatan komunikasi matematis. Selain itu, melibatkan dunia nyata mereka dalam pembelajaran. Yaitu pembelajaran yang membuat siswa mampu menghubungkan benda nyata, gambar, diagram serta mengkomunikasikan secara lisan, tulisan pemahaman mereka dalam menyelesaikan permasalahan kehidupan nyata. Hal ini tentunya akan mengindikasikan bahwa matematika merupakan bagian dari aktivitas siswa dan berguna bagi kehidupan mereka. Pembelajaran yang diduga cocok untuk kondisi tersebut adalah pembelajaran dengan menggunakan strategi REACT.

Strategi REACT merupakan strategi pembelajaran yang cocok untuk meningkatkan kemampuan komunikasi matematis siswa. Strategi ini terdiri atas lima aspek yaitu Relating, Eksperiencing, Applying, Cooperating dan Transferring (Crawford, 2001).

Relating lebih menekankan pada pengalaman hidup/belajar. Siswa mampu menghubungkan pengetahuan yang telah dimiliki atau menghubungkan konsep materi dengan kehidupan sehari-hari mereka. Experiencing berarti memberikan pengalaman belajar siswa melalui kegiatan membangun dan menemukan pengeta-huan sendiri. Pengalaman tersebut dapat diperoleh dengan melakukan kegiatan yang melibatkan keaktifan siswa dalam belajar, sehingga siswa akan lebih mudah mengerti dan memahami konsep (Ni'mah, 2007). Salah satunya dengan menggunakan bantuan LKS yang telah disusun sedemikian rupa untuk membantu siswa dalam pembelajaran.

Applying yang terfokus pada bagaimana siswa memahami konsep dan menggunakannya dalam menyelesaikan masalah. Dalam hal ini guru berperan sebagai fasilitator bagi siswa. Jika terdapat siswa yang mengalami kesulitan dalam menyelesaikan masalah, maka guru meminta pendapat kepada siswa lainnya untuk dapat membantu menyelesaikan masalah tersebut.

Cooperating berarti mendiskusikan teknik, metode, strategi dan solusi yang telah diperoleh dengan teman sekelompok, sehingga kemampuan komunikasi matematis siswa dapat dilihat pada tahap ini. Dalam hal ini siswa akan terlatih untuk dapat berkomunikasi secara baik dengan orang lain. Cara belajar dengan berkerja sama, tukar pendapat, dan komunikasi dengan siswa lain dapat membantu siswa menguasai konsep. Sesuai dengan yang dikatakan Crawford (2001), bahwa pembelajaran kolaboratif dapat meningkatkan hasil belajar siswa, dibandingkan dengan pembelajaran melalui metode kompetitif dan individualistik.

Transfering berarti mengembangkan pengetahuan atau menggunakan pengetahuan yang telah diperoleh pada konteks permasalahan yang baru. Setelah siswa paham terhadap suatu konsep yang dipelajarinya, maka selanjutnya siswa menerapkan atau memanfaatkan pengetahuan yang telah 
diperolehnya ke dalam konteks yang baru.

Pembelajaran menggunakan strategi REACT dipilih karena mengikutsertakan siswa dalam penerapan konsep masyarakat belajar dan tanggung jawab bersama, menekankan pada kegiatan proses pembelajaran yang berbasis pada aktivitas siswa dalam melakukan eksplorasi dan penyelidikan, refleksi yang dilakukan oleh guru dan siswa, serta siswa diberi kesempatan untuk menemukan makna belajar dan mengembangkan potensi dirinya.

Penelitian ini dilakukan untuk melihat peningkatan kemampuan komunikasi matematis siswa setelah diberikan perlakuan menggunakan strategi REACT, dengan memperhatikan kemampuan awal yang dimiliki oleh siswa, yaitu tinggi, sedang dan rendah. Selain itu, interaksi antara pendekatan pembelajaran dan kemampuan awal siswa juga dilihat, untuk mengetahui apakah pendekatan pembelajaran dan kemampuan awal siswa mempengaruhi peningkatan kemampuan komunikasi matematis.

\section{KAJIAN PUSTAKA}

Strategi pembelajaran yang digunakan oleh guru menentukan keberhasilan seorang siswa, dengan demikian seorang guru dituntut untuk selalu memberikan inovasi baru dalam bidang pendidikan untuk membimbing siswa menemukan keberhasilan mereka. Salah satunya adalah strategi REACT. Strategi REACT merupakan salah satu strategi yang dapat menciptakan pembelajaran matematika yang lebih bermakna, karena mengaitkan materi pembelajaran dengan dunia nyata. Pembelajaran dengan menggunakan strategi REACT adalah pembelajaran yang menekankan kepada aspek menghubungkan (Relating), mengalami (Experiencing), menerapkan (Applying), bekerja sama (Cooperating) dan mentransfer pengetahuan yang telah didapat (Transferring). Strategi ini diharapkan mampu meningkatkan kemampuan komunikasi matematis siswa.
Kemampuan komunikasi matematis adalah kemampuan siswa dalam menyampaikan ide atau informasi yang diperoleh sesuai dengan penafsirannya sendiri. Indikator komunikasi matematis yang digunakan adalah (a) menghubungkan benda nyata, gambar dan diagram ke dalam ide matematika, (b) kemampuan menulis, yaitu berupa kemampuan memberikan penjelasan atau menyatakan peristiwa yang dikemukakan dalam bahasa atau simbol matematika, (c) kemampuan menjelaskan ide, situasi dan relasi matematika dengan benda nyata, gambar, grafik, tabel dan aljabar, serta (d) membuat konjektur, menyusun argumen, merumuskan definisi dan generalisasi.

Salah satu faktor yang menentukan keberhasilan siswa dalam belajar adalah kemampuan awal mereka. Kemampuan awal adalah kemampuan yang telah dimiliki oleh siswa sebelum mereka mengikuti pelajaran dengan memberikan suatu tes pada pertemuan pertama. Kemampuan ini dapat berupa pemahaman siswa terhadap materi awal (materi prasyarat) yang harus mereka kuasai sebelum masuk kepada materi baru. Kemampuan awal siswa penting untuk diketahui guru sebelum ia memulai pembelajarannya, karena dengan demikian dapat diketahui apakah siswa telah mempunyai pengetahuan yang merupakan prasyarat untuk mengikuti pembelajaran. Dengan mengetahui hal tersebut, guru dapat merancang pembelajaran dengan lebih baik.

\section{METODOLOGI}

a. Populasi dan Sampel

Populasi dari penelitian ini adalah seluruh siswa kelas V SD Negeri Kota Solok yang terdaftar pada semester I tahun pelajaran 2012/2013 yang terdiri dari 20 buah sekolah. Sampel dipilih secara Random Sampling, sehingga terpilih siswa kelas V SD Negeri 03 Kampung Jawa Solok sebagai kelas eksperimen, dan siswa kelas V SD Negeri 04 IX Korong Solok sebagai kelas kontrol. Kedua kelas dibagi 
lagi menjadi kategori tinggi, sedang dan rendah berdasarkan kemampuan awal mereka.

b. Desain Penelitian

Penelitian ini menggunakan pendekatan kuantitatif dalam bentuk Quasi Experimental, dengan rancangan Randomized PretestPosttest Control Group Design.

c. Alur Pengolahan Data

Instrumen yang digunakan untuk mengumpulkan data adalah tes kemampuan awal siswa, dan tes kemampuan komunikasi matematis siswa. Tes kemampuan awal siswa diberikan sebelum melaksanakan penelitian untuk mengetahui kemampuan awal siswa sebelum penelitian dilakukan. Dari hasil kemampuan awal ini, siswa dikelompokkan berdasarkan keampuan awal tinggi, sedang dan rendah. Kemudian diberikan pretest untuk mengetahui kemam-puan komunikasi matematis siswa sebelum membahas materi pecahan. Setelah perlakuan selesai, diberikan posttest yang soalnya sama dengan pretest. Untuk melihat peningkatan kemampuan komunikasi matematis di kedua kelas sampel, maka hasil posttest dan pretest dianalisis menggunakan rumus gain ternormalisasi.

\section{HASIL DAN PEMBAHASAN}

a. Deskripsi Hasil Tes

1) Kemampuan Komunikasi Matematis Siswa

Untuk memperoleh gambaran kemampuan komunikasi matematis siswa, data dianalisis secara deskriptif agar dapat diketahui rata-rata, dan simpangan baku siswa berdasarkan pretest, posttest dan peningkatannya. Hasil analisis deskriptif tersebut dapat dilihat pada Tabel

1.

Tabel 1. Hasil Analisis Data Pretest, Posttest dan Peningkatan Kemampuan Komunikasi Matematis

\begin{tabular}{|c|c|c|c|c|c|}
\hline Kelas & Nilai & $\mathbf{N}$ & $\bar{x}$ & $\mathrm{~s}^{2}$ & $\mathbf{S}$ \\
\hline \multirow{3}{*}{ Eksperimen } & Pretest & \multirow{3}{*}{32} & 3,25 & 2,39 & 1,55 \\
\hline & Posttest & & 12,81 & 7,71 & 2,78 \\
\hline & Gain & & 0,76 & 0,04 & 0,19 \\
\hline \multirow{3}{*}{ Kontrol } & Pretest & \multirow{3}{*}{24} & 3,29 & 2,82 & 1,68 \\
\hline & Posttest & & 10,13 & 10,72 & 3,27 \\
\hline & Gain & & 0,54 & 0,06 & 0,24 \\
\hline
\end{tabular}

Pada Tabel, terlihat bahwa rata-rata skor gain untuk kemampuan komunikasi matematis siswa kelas eksperi-men dengan strategi REACT, lebih tinggi dibandingkan dengan kelas kontrol yang diajar dengan pembelajaran konvensional. Nilai gain ini menunjukkan bahwa peningka-tan dari skor pretest dan skor posttest kelas eksperimen lebih tinggi dibandingkan dengan kelas kontrol.

2) Kemampuan Komunikasi Mate-matis Siswa Berdasarkan Ke-mampuan Awal

Hasil analisis pretest, posttest dan peningkatan kemampuan komunikasi mate-matis berdasarkan kemam-puan awal siswa kelas eksperimen dan kelas kontrol dapat dilihat pada Tabel berikut. 
Tabel 2. Hasil Analisis Pretest, Posttest dan Peningkatan Kemampuan Komunikasi Matematis Berdasarkan Kemampuan Awal

\begin{tabular}{|c|c|c|c|c|c|c|c|c|}
\hline Kelas & Nilai & $\begin{array}{l}\text { Kem. } \\
\text { Awal }\end{array}$ & $\mathbf{n}$ & $\bar{x}$ & 2 & $\mathbf{S} \quad \mathbf{s}$ & $X_{\text {mak }}$ & $X_{m i}$ \\
\hline \multirow{9}{*}{ Eksperimen } & \multirow{3}{*}{ Pretest } & Tinggi & 7 & 5,14 & 3,14 & 1,77 & 7 & 3 \\
\hline & & Sedang & 21 & 2,81 & 0,96 & 0,98 & 5 & 1 \\
\hline & & Rendah & 4 & 2,25 & 0,92 & 0,96 & 3 & 1 \\
\hline & \multirow{3}{*}{ Posttest } & Tinggi & 7 & 14,86 & 0,48 & 0,69 & 16 & 14 \\
\hline & & Sedang & 21 & 13 & 5,8 & 2,41 & 16 & 7 \\
\hline & & Rendah & 4 & 8,25 & 2,25 & 1,5 & 9 & 6 \\
\hline & \multirow{3}{*}{ Gain } & Tinggi & 7 & 0,89 & 0,01 & 0,64 & 1 & 0,8 \\
\hline & & Sedang & 21 & 0,78 & 0,03 & 0,17 & 1 & 0,4 \\
\hline & & Rendah & 4 & 0,44 & 0,01 & 0,11 & 0,53 & 0,29 \\
\hline \multirow{9}{*}{ Kontrol } & \multirow{3}{*}{ Pretest } & Tinggi & 4 & 4,5 & 0,33 & 0,58 & 5 & 4 \\
\hline & & Sedang & 14 & 3,21 & 3,26 & 1,81 & 6 & 1 \\
\hline & & Rendah & 6 & 2,67 & 2,67 & 1,63 & 5 & 1 \\
\hline & \multirow{3}{*}{ Posttest } & Tinggi & 4 & 13 & 2,67 & 1,63 & 15 & 11 \\
\hline & & Sedang & 14 & 10,86 & 7,82 & 2,79 & 16 & 6 \\
\hline & & Rendah & 6 & 6,5 & 3,5 & 1,87 & 10 & 5 \\
\hline & \multirow{3}{*}{ Gain } & Tinggi & 4 & 0,74 & 0,02 & 0,15 & 0,91 & 0,55 \\
\hline & & Sedang & 14 & 0,6 & 0,05 & 0,21 & 1 & 0,33 \\
\hline & & Rendah & 6 & 0,29 & 0,01 & 0,12 & 0,5 & 0,18 \\
\hline
\end{tabular}

3) Kemampuan Komunikasi Matematis Siswa Berdasarkan Indikator Soal

Hasil analisis peningkatan kemampuan komunikasi matematis berdasarkan indikator soal untuk siswa kelas eksperimen dan kelas kontrol dapat dilihat pada Tabel berikut.

Tabel 3. Hasil Analisis Data Peningkatan Kemampuan Komunikasi Matematis Berdasarkan Indikator Soal

\begin{tabular}{|c|c|c|c|c|c|c|}
\hline \multirow{3}{*}{ Kelas } & \multirow{3}{*}{ Kem.Awal } & $\mathbf{N}$ & \multicolumn{4}{|c|}{ Indikator Soal } \\
\cline { 3 - 7 } & Tinggi & 7 & 1 & 1 & 0,96 & 0,31 \\
\cline { 2 - 7 } Eksperimen & Sedang & 21 & 0,74 & 0,84 & 0,8 & 0,7 \\
\cline { 2 - 7 } & Rendah & 4 & 0,56 & 0,65 & 0,56 & 0,17 \\
\cline { 2 - 7 } & Total & $\mathbf{3 2}$ & $\mathbf{0 , 7 7}$ & $\mathbf{0 , 8 5}$ & $\mathbf{0 , 8 0}$ & $\mathbf{0 , 5 5}$ \\
\hline \multirow{4}{*}{ Kontrol } & Tinggi & 4 & 0,63 & 1 & 0,63 & 0,5 \\
\cline { 2 - 7 } & Sedang & 14 & 0,32 & 0,90 & 0,57 & 0,54 \\
\cline { 2 - 7 } & Rendah & 6 & 0,08 & 0,71 & 0,21 & 0,15 \\
\cline { 2 - 7 } & Total & $\mathbf{2 4}$ & $\mathbf{0 , 3 1}$ & $\mathbf{0 , 8 7}$ & $\mathbf{0 , 4 9}$ & $\mathbf{0 , 4 3}$ \\
\hline
\end{tabular}

b. Analisis Data

Sebelum melakukan uji kesamaan rata-rata, terlebih dahulu dilakukan uji normalitas dan homogeni-tas variansi. Untuk uji normalitas distribusi data digunakan uji Kolmogorov-Smirnov, sedangkan untuk homogenitas 
variansi digunakan uji Levene, dan terbukti bahwa data peningkatan kemampuan komunikasi matematis siswa berdistribusi normal dan bahwa variansi kelas sampel, untuk semua kemampuan awal mempunyai variansi yang homogen. Karena data berdistribusi normal dan variansinya homogen, maka digunakan uji $t$ untuk uji kesamaan rata-rata.

Hasil analisis mengenai perbedaan peningkatan kemampuan komunikasi matematis siswa kelas eksperimen dan kontrol, dapat dilihat pada Tabel berikut

Tabel 4. Hasil Perhitungan Peningkatan Kemampuan Komunikasi Matematis

\begin{tabular}{|c|c|c|c|c|c|}
\hline Kelas & $\mathbf{N}$ & Rata-Rata & thitun & df & Sig. \\
\hline Eksperimen & 32 & 0,7588 & \multirow{2}{*}{3,730} & \multirow{2}{*}{54} & \multirow{2}{*}{0,000} \\
\hline Kontrol & 24 & 0,5432 & & & \\
\hline
\end{tabular}

Pada Tabel, diperoleh nilai Sig $<\alpha$, yaitu $0,000<0,05$, dan dapat disimpulkan bahwa $\mathrm{H}_{0}$ ditolak dan $\mathrm{H}_{1}$ diterima. Artinya, terdapat perbedaan peningkatan kemampuan komunikasi matematis siswa. Rata-rata nilai peningkatan kemampuan komunikasi matematis siswa pada kelas eksperi- men, lebih tinggi daripada rata-rata nilai peningkatan kemampuan komunikasi matematis siswa kelas kontrol.

Peningkatan kemampuan komunikasi matematis siswa berdasarkan kemampuan awal dapat dilihat pada Tabel berikut.

\section{Tabel 5. Hasil Perhitungan Peningkatan Kemampuan Komunikasi Matematis Siswa Berdasarkan Kemampuan Awal}

\begin{tabular}{|c|c|c|c|c|c|c|}
\hline $\begin{array}{c}\text { Kemampua } \\
\text { n awal }\end{array}$ & Kelas & $\mathbf{N}$ & Rata-Rata & $\begin{array}{l}\text { thitun } \\
\text { g }\end{array}$ & df & Sig. \\
\hline \multirow[t]{2}{*}{ Tinggi } & Eksperimen & 7 & 0,8906 & \multirow[b]{2}{*}{2,408} & \multirow[b]{2}{*}{9} & \multirow[b]{2}{*}{0,0195} \\
\hline & Kontrol & 4 & 0,7386 & & & \\
\hline \multirow[t]{2}{*}{ Sedang } & Eksperimen & 21 & 0,7764 & \multirow[b]{2}{*}{2,787} & \multirow[b]{2}{*}{33} & \multirow[b]{2}{*}{0,0045} \\
\hline & Kontrol & 14 & 0,5969 & & & \\
\hline \multirow[t]{2}{*}{ Rendah } & Eksperimen & 4 & 0,4355 & \multirow[b]{2}{*}{2,038} & \multirow[b]{2}{*}{8} & \multirow{2}{*}{0,038} \\
\hline & Kontrol & 6 & 0,2878 & & & \\
\hline
\end{tabular}

Dilihat dari segi kemampuan awal siswa, diperoleh bahwa rata-rata nilai peningkatan kemampuan komunikasi matematis siswa yang mempunyai kemampuan awal tinggi, sedang dan rendah pada kelas eksperimen, lebih tinggi daripada rata-rata nilai peningkatan kemampuan komunikasi matematis siswa yang mempunyai kemampuan awal tinggi, sedang dan rendah pada kelas kontrol. Dapat dikatakan bahwa peningkatan kemampuan komunikasi matematis siswa yang berkemampuan awal tinggi, sedang dan rendah pada kelas eksperimen lebih baik daripada kelas kontrol. Hal ini terjadi karena pada saat menerapkan strategi REACT, siswa secara berkelompok bekerja sama dan berbagi ide, untuk menemukan konsep dari materi pecahan dengan menyelesaikan kegiatan yang ada pada LKS yang diberikan. Hasil analisis ini sesuai dengan yang diungkapkan oleh 
Crawford (2001), bahwa strategi REACT memberi peluang yang lebih baik bagi siswa, untuk dapat mengembangkan dan meningkatkan kemampuan komunikasi matematis yang dimiliki.

Untuk melihat interaksi antara pendekatan pembelajaran dengan ke- mampuan awal siswa, dalam mempengaruhi peningkatan kemampuan komunikasi matematis siswa, maka digunakan uji ANAVA dua arah seperti terlihat pada Tabel 6 dan Gambar 1 berikut.

\section{Tabel 6. Hasil Perhitungan Interaksi Antara Pendekatan Pembelajaran dengan Kemampuan Awal Siswa dalam Mempengaruhi Peningkatan Kemampuan Komunikasi Matematis}

\begin{tabular}{|c|c|c|c|c|c|}
\hline $\begin{array}{c}\text { Sumber } \\
\text { Keragaman }\end{array}$ & $\begin{array}{c}\text { Jumlah } \\
\text { Kuadrat }\end{array}$ & $\begin{array}{c}\text { Derajat } \\
\text { Bebas }\end{array}$ & $\begin{array}{c}\text { Kuadrat } \\
\text { Tengah }\end{array}$ & $\boldsymbol{F}_{\text {hitu }}$ & Sig. \\
\hline $\begin{array}{c}\text { Kemampuan } \\
\text { Awal * Model } \\
\text { Pembelajaran }\end{array}$ & 0,003 & 2 & 0,001 & 0,052 & 0,950 \\
\hline Galat & 1,343 & 50 & 0,027 & & \\
\hline
\end{tabular}

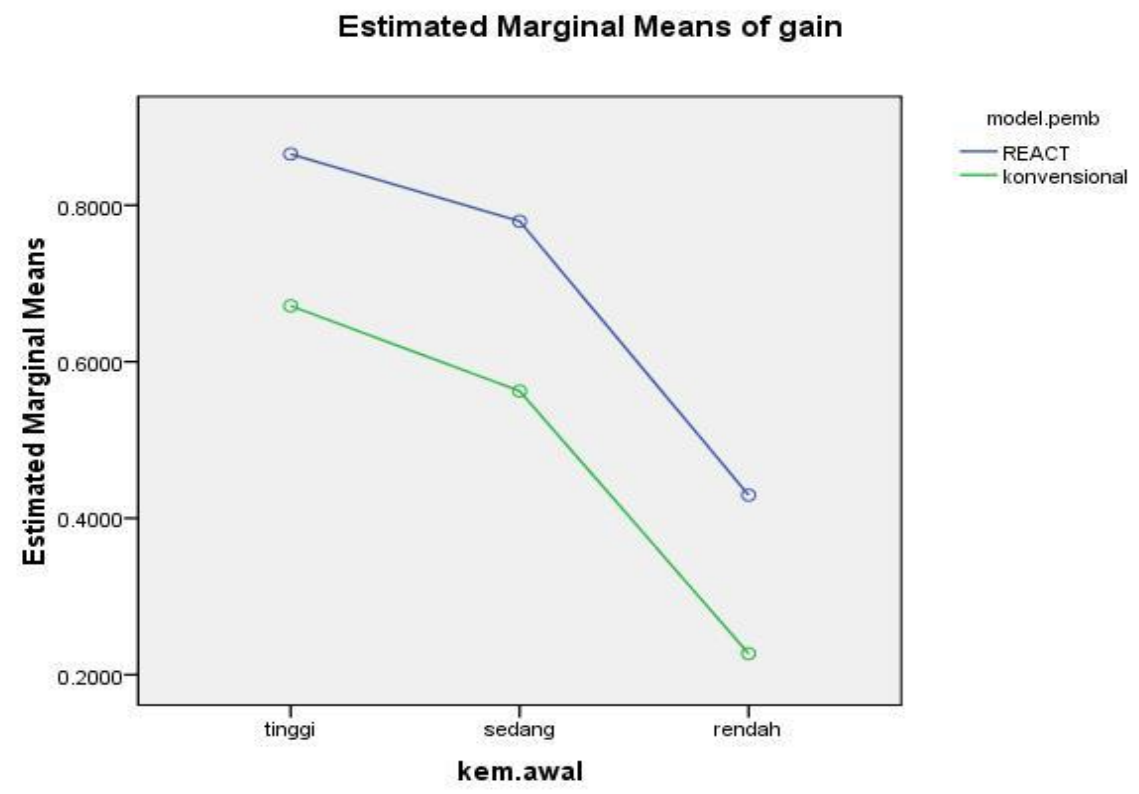

\section{Gambar 1. Grafik Interaksi Kemampuan Komunikasi Matematis}

Berdasarkan tabel dan bentuk grafik yang terbentuk, dapat disimpulkan bahwa tidak terdapat interaksi antara pendekatan pembelajaran dengan kemampuan awal siswa dalam mempengaruhi peningkatan kemampuan komunikasi matematis siswa. Dengan demikian dapat dikatakan, bahwa strategi REACT dapat digunakan oleh siswa tanpa memperhatikan kemampuan awal tinggi, sedang maupun rendah. Hal ini terjadi karena siswa belum terbiasa menggunakan strategi REACT dalam pembelajaran yang menuntut mereka menemukan konsep, sehingga mereka saling berbagi ide maupun pendapat dalam diskusi kelompok untuk menemukan konsep dan menyelesaikan masalah yang diberikan. Dalam diskusi kelompok, semua siswa memiliki kesempatan yang 
sama, sehingga tidak hanya siswa berkemampuan awal tinggi saja yang mampu mengkomunikasikan apa yang mereka pahami, namun siswa berkemampuan awal rendahpun mampu mempresentasikan hasil diskusi mereka.

Tidak adanya interaksi ini menunjukkan bahwa perbedaan kemampuan awal dan pendekatan pembelajaran tidak mempengaruhi peningkatan kemampuan komunikasi matematis siswa. Perbedaan peningkatan kemampuan komunikasi matematis siswa hanya disebabkan oleh perbedaan pembelajaran yang digunakan. Hal ini sesuai dengan ungkapan Irianto (2010), bahwa interaksi merupakan kebersamaan antara faktor dalam mempengaruhi variabel bebas, dengan sendiri pengaruh faktor-faktor secara mandiri telah dihilangkan.

Dalam menyelesaikan soal tes yang diberikan, siswa dituntut untuk dapat memahami soal berdasarkan indikator kemampuan komunikasi matematis. Berdasarkan analisis terhadap peningkatan kemampuan komunikasi matematis, siswa kelas eksperimen lebih unggul dibandingkan dengan kelas kontrol untuk indikator soal nomor 1, 3 dan 7. Indikatornya adalah (1) menjelaskan ide situasi dan relasi matematika dengan benda nyata, gambar, grafik, tabel dan aljabar, (2) membuat konjektur, menyusun argumen, merumuskan definisi dan generalisasi serta (3) menghubungkan benda nyata, gambar dan diagram ke dalam ide matematika.

Berdasarkan analisis terhadap lembar jawaban siswa, terlihat bahwa sebagian besar siswa telah mampu mengkomunikasikan jawaban yang mereka dapatkan dengan menggunakan bantuan gambar atau benda konkrit. Namun beberapa siswa masih ada yang salah dalam melakukan perhitungan. Hal ini disebabkan karena siswa kurang memahami soal dengan baik dan tidak hati-hati dalam melakukan perhitungan. Siswa kelas kontrol sebagian besar melakukan kesalahan dalam menyelesaikan per- masalahan yang menuntut pemahaman lebih dari siswa. Mereka kurang mampu membuat konjektur, menyusun argumen dari soal. Jika siswa memahami maksud dan tujuan dari soal yang diberikan, maka mereka dapat membuat konjektur dan menyatakan pendapat mereka untuk membantu menyelesaikan masalah.

Berdasarkan hasil dan pembahasan tersebut dapat dikatakan bahwa strategi REACT dapat meningkatkan kemampuan komunikasi matematis siswa, sehingga mereka dapat menggunakan konsep matematika terutama konsep Pecahan dalam memecahkan permasalahan dunia nyata, dan mereka yakin bahwa matematika sangat berguna bagi kehidupan mereka.

\section{KESIMPULAN DAN SARAN}

a. Kesimpulan

Berdasarkan hasil pengolahan data dan analisis yang telah dikemukakan sebelumnya, diperoleh kesimpulan bahwa:

1) Kemampuan komunikasi matematis siswa yang menggunakan strategi REACT, lebih baik daripada siswa yang menggunakan model pembelajaran konvensional.

2) Kemampuan komunikasi matematis siswa yang mempunyai kemampuan awal tinggi dengan menggunakan strategi REACT, lebih baik daripada siswa yang mempunyai kemampuan awal tinggi dengan menggunakan model pembelajaran konvensional.

3) Kemampuan komunikasi matematis siswa yang mempunyai kemampuan awal sedang dengan menggunakan strategi REACT, lebih baik daripada siswa yang mempunyai kemampuan awal sedang dengan menggunakan model pembelajaran konvensional.

4) Kemampuan komunikasi matematis siswa yang mempunyai kemampuan awal rendah dengan menggunakan strategi 
REACT, lebih baik daripada siswa yang mempunyai kemampuan awal rendah dengan menggunakan model pembelajaran konvensional.

5) Tidak terdapat interaksi antara pendekatan pembelajaran dengan kemampuan awal siswa dalam mempengaruhi peningkatan kemampuan komunikasi matematis siswa.

b. Saran

Berdasarkan kesimpulan di atas, maka penelitian ini memberikan saran-saran sebagai berikut: (1) Pembelajaran menggunakan strategi REACT, hendaknya dapat terus dikembangkan dan dijadikan sebagai salah satu alternatif dalam proses pembelajaran bagi guru SD Negeri 03 Kampung Jawa dan 04 IX Korong Solok, karena terbukti dapat meningkatkan kemampuan komunikasi matematis siswa dan (2) Perlu penelitian lebih lanjut mengenai implementasi pembelajaran menggunakan strategi REACT, untuk pokok bahasan lain.

\section{DAFTAR PUSTAKA}

Crawford, L.M. (2001). Teaching Contextually: Research, Rational, and Technique for Imploving Student Motivation and Achie-vement in Mathematics Science. Texas: CCI Publishing, INC

Hake, R. R. (1999). Analyzing Change/Gain Scores. Woodland Hills: Dept. Of Physics, Indiana University. Online (http://www.physics.indiana.du/ sdi/Analyzing-ChangeGain.pdf. Diakses tanggal 5 Januari 2013)
Iskandar, Arif. (2010). "Pengaruh Pendekatan Pemecahan Masalah terhadap Pemahaman Konsep, Kemampuan Komunikasi dan Pemecahan Masalah Matematika Mahasiswa PGMI UIN Riau”. Tesis. Padang: UNP

Jihad, Asep. (2008). Pengembangan Kurikulum Matematika (Tinjauan Teoritis dan Historis). Bandung: Multi Pessindo

NCTM. (2000). Principles and Standards for School Mathematics. Reston VA: Authur

Ni'mah, Nunin. (2007). Penerapan Pembelajaran Kontekstual Strategi REACT untuk Meningkatkan Prestasi Belajar pada Mata Pelajaran IPS Ekonomi di Kelas VII SMP Kartika IV-8 Malang. Skripsi. Malang: UIN Malang. Online (http://lib.uinmalang.ac.id/thesi s/fullchapter/03160025-nuninnimah.ps. Diakses tanggal 8 Sepetember 2012)

Rohati. (2011). "Pengembangan Bahan Ajar Materi Bangun Ruang dengan Menggunakan Strategi Relating, Experiencing, Applying, Cooperating, Transfering (REACT) di Sekolah Mengenah Pertama". Jurnal Edumatica. I (2): 20882157

Slameto. (2003). Belajar dan FaktorFaktor yang Mempengaruhinya. Jakarta: Rineka Cipta

Suherman, Erman. (2003). Strategi Pembelajaran Matematika Kontemporer (edisi revisi). Bandung: UPI. 